\title{
Sunlight and free markets: an urban political ecological perspective on social housing in Victorian London (1850-1914)
}

\author{
Anna Christine Grant ${ }^{1 \star}$ (D) and Jeremia Njeru ${ }^{2 \dagger}$ \\ ${ }^{1}$ Carnegie Mellon University, Department of History, 5000 Forbes Ave., Pittsburgh PA 15213, USA and \\ ${ }^{2}$ Central College, Department of Behavioral Sciences, Campus Box 061, 812 University St, Pella, IA 51219, \\ USA \\ ${ }^{\star}$ Corresponding author. Email: cregier@andrew.cmu.edu
}

\begin{abstract}
Urban political ecology (UPE) provides an appropriate framework to consider the ways in which natural elements and concepts of nature have been incorporated into built environments, because of its emphasis on and elaboration of the concept of socio-natures and its focus on how the costs and benefits of these natural elements are apportioned between people of different classes in cities. This article considers how reformers' ideas about nature shaped the kinds of social housing they developed in nineteenth- and early twentieth-century London.
\end{abstract}

On Red Cross Way in south-west London, a small row of quaint-looking cottages looks out over a compact community garden, recently restored to its original function after lying paved over for several decades. A few miles away, artisans' cottages and prestigious homes share space in a planned suburb overlooking Hampstead Heath. Both present an aesthetic contrast with the uniform brick façade of a building in Soho bearing the inscription 'Model Dwellings for Families'. Yet all were produced between about 1850 and 1910 in response to the same impulse: middle-class activists' concern about the housing conditions of London's working classes. Their differing forms reflected changes in reformers' conceptions of the value and role of nature in working-class urban environments.

\footnotetext{
${ }^{\dagger}$ Special thanks to all those who read earlier versions of this article, for their insights and encouragement: in particular, Joe Hodge at West Virginia University who oversaw the initial research, and at Carnegie Mellon, Kate Lynch, Noah Theriault and Ema Grama for their encouragement, as well as the faculty and doctoral students who workshopped the paper, in particular Ed Russell and John Soluri for sharing their expertise on nature in the nineteenth-century city. The authors would also like to thank the two anonymous reviewers, as well as the editors at Urban History, for valuable advice and support.

(c) The Author(s), 2022. Published by Cambridge University Press. This is an Open Access article, distributed under the terms of the Creative Commons Attribution-NonCommercial-ShareAlike licence (http://creativecommons.org/licenses/ by-nc-sa/4.0), which permits non-commercial re-use, distribution, and reproduction in any medium, provided the same Creative Commons licence is used to distribute the re-used or adapted article and the original article is properly cited. The written permission of Cambridge University Press must be obtained prior to any commercial use.
} 
Like other large cities across the world, London has long suffered a shortfall of affordable housing for the many essential, yet low-waged workers on whom the city's economy depends, as well as those unable to work due to age, disability or the vagaries of the labour market. In the nineteenth century, spurred to action by devastating epidemics, reformers ventured into working-class districts, where multitudes lived packed into decrepit buildings utterly lacking in the necessary facilities for maintaining physical and mental health. Decrying these conditions, they endeavoured to create something better. But building urban homes is never a simple matter. Any home must protect its residents from dangers, such as weather, as well as noxious substances and organisms, including vermin, viruses and sometimes other people. This much is evident, but homes also play a role in regulating our mental health and organizing our social existence, as nineteenth-century reformers realized. Transforming London's notorious slums thus involved not only bricks and mortar, but a complex and contested structure of concepts, meanings and socio-natural relationships buttressed by logics of hierarchy and wealth. In the three case-studies that this article examines, reformers built into their housing concepts of nature that changed over time, and that intersected with a myriad of ideas about such things as work, hygiene, respectability and morality.

To understand, then, how and why nineteenth-century housing reformers built the developments they did requires disentangling 'the interwoven knots of social process, material metabolism and spatial form' that have shaped these urban landscapes. ${ }^{1}$ To do so, this article engages with the work of urban political ecologists, whose interdisciplinary field encourages urban scholars to uncover the processes by which people in cities establish, maintain or resist power as they participate in the ecology of the city. Urban political ecology (UPE) is useful for analysing the role of both non-human elements and concepts of nature in producing social housing, because of its articulation of the concept of socio-natures. ${ }^{2}$ UPE considers the questions 'Who pays?' and 'Who benefits?' in the production of urban environments, by investigating the political context within which this occurs. ${ }^{3}$ Since most nineteenth-century social housing was created by the middle class for the working class, under an ethos that attempted to combine business principles and a modest profit with philanthropy and social justice, and informed by concepts of nature, these questions are highly relevant to the history of social housing.

To tease out these connections, we first investigate how views of laissez-faire liberal political economy as a set of natural laws contributed to the idea that cities were artificial or unnatural. The next section focuses on three Londoners: the architect

\footnotetext{
${ }^{1}$ E. Swyngedouw and N. Heynen, 'Urban political ecology, justice and the politics of scale', Antipode, 35 (2003), 906.

${ }^{2} \mathrm{E}$. Swyngedouw and M. Kaika, 'The environment of the city...or the urbanization of nature', in G. Bridge and S. Watson (eds.), A Companion to the City (Oxford, 2000); E. Swyngedouw and M. Kaika, 'The urbanization of nature: great promises, impasse, and new beginnings', in G. Bridge and S. Watson (eds.), The New Blackwell Companion to the City (Chichester, 2011); M. Gandy, Concrete and Clay: Reworking Nature in New York City (Cambridge, MA, 2002).

${ }^{3}$ N. Heynen, E. Swyngedouw and M. Kaika, In the Nature of Cities: Urban Political Ecology and the Politics of Urban Metabolism (London, 2006); R. Holifield and N. Schuelke, 'The place and time of the political in urban political ecology: contested imaginations of a river's future', Annals of the Association of American Geographers, 105 (2015), 294-303.
} 
George Godwin, the housing reformer and conservationist Octavia Hill and the social and educational activist Henrietta Barnett. Each played a role in promoting a particular style of social housing in the capital: Godwin for the model dwellings companies, Hill for renovating and managing existing housing and campaigning for open spaces in working-class areas and Barnett primarily for the Hampstead Garden Suburb. ${ }^{4}$ We investigate each one's ideas about how nature could be used to improve working-class housing, arguing that these ideas about nature were profoundly influenced by their notions of political economy and their need to appeal to a business constituency to attract the needed investment. We show that over time, reformers increasingly viewed the unreformed urban slums as artificial or antithetical to nature. We explore changing concepts of urban nature to reveal the utility to Victorian reformers of a concept of nature that appeared eternal and thus unquestionable, but which in fact allowed considerable flexibility in creating and justifying solutions to urban problems while leaving intact the sociopolitical relations that had permitted them to arise.

\section{Urban political ecology}

UPE shares many of its interests with urban environmental history, although the latter has been criticized for 'downplaying, in some cases ignoring, the importance of urban political economy'. ${ }^{5}$ This article aims to address this issue by deploying a UPE framework, which seeks to expose how social and political systems and processes interact with ecological ones in the production of urban landscapes. ${ }^{6}$ If UPE's founding scholars in the 1990s were predominantly geographers, the field now draws from anthropology, sociology, science and technology studies, and an array of social sciences, and defining it is not simple. ${ }^{7}$ However, UPE scholars share a set of fundamental questions. They investigate how political and institutional configurations give certain groups power to transform land and ecosystems, materially and discursively, in ways that benefit them at the expense of marginalized groups. They study the unequal distribution of environmental benefits and costs among different human actors. They conceptualize the process of urbanization as constituted by metabolic flows of resources and of humans. ${ }^{8}$ Above all, these scholars challenge apolitical ecologies by working 'to "denaturize" certain social and

\footnotetext{
${ }^{4}$ This article limits itself to London as a case-study of change over time in thinking and practice about urbanized nature and housing reform, and because being active in the capital lent visibility to these projects.

${ }^{5} \mathrm{~N}$. Heynen, 'Green urban political ecologies: toward a better understanding of inner-city environmental change', Environment and Planning A: Economy and Space, 38 (2006), 501.

${ }^{6}$ The complex history of political debates over affordable housing in the Victorian and Edwardian eras is beyond the scope of this article, which focuses specifically on notions of political economy and how they influenced the kinds of urban spaces that were designated 'natural'.

${ }^{7}$ E. Swyngedouw, 'The city as a hybrid: on nature, society and cyborg urbanization', Capitalism Nature Socialism, 7 (1996), 65-80, is often cited as the field's founding text.

${ }^{8}$ See, for example, M. Kaika, City of Flows: Modernity, Nature, and the City (New York, 2005); other authors have focused on the role of one resource, such as water: M. Gandy, The Fabric of Space: Water, Modernity, and the Urban Imagination (Cambridge, MA, 2014); of course, the materials (and humans) that flow in and through cities are not always valued resources, and some scholars have studied the flow of waste materials and pollution: J. Njeru, 'The urban political ecology of plastic bag waste problem in Nairobi, Kenya', Geoforum, 37 (2006), 1046-58; D. Amuzu, 'Environmental injustice of informal e-waste
} 
environmental conditions, showing them to be the contingent outcomes of power, and not inevitable'. ${ }^{9}$ They deconstruct discourses about nature that - often deliberately - obscure the political choices and stances that underpin them, presenting themselves as universal, inevitable or normative. Malthusian ideas about population growth, for example, posit famine as nature's way of reducing the poor rates, the inevitable consequence of high birth rates among the poor, thus avoiding questions about the just distribution of wealth. Some political ecologists write from a Marxian perspective, seeking to expose the contradictions and tensions inherent in the ideology and workings of capitalism. Others, less committed to a particular ideology, focus on issues of social justice as they interact with ecology.

Like urban environmental history, urban political ecology is a recent but rapidly growing field of study that rejects the nature-society dualisms that characterized an earlier generation of urban studies. At first, scholars interested in ecology or environmental issues, influenced by the twentieth-century view that cities were less natural than wild or rural landscapes, excluded them from their sphere of interest. Those drawn to the fields because of their engagement in environmentalism have often viewed nature as something to be saved from human depredations; cities were too hopeless a case to be included. Most of the early work in political ecology focused on rural areas in the global South. Researchers noted that discourses about wildlife preservation and environmental protection either erased human activity from the landscape or blamed the poor for ecological destruction. Such discourses actually enabled social injustices in the name of conservation, as they ignored the role of social-power relationships in the transformation of ecological processes. Early UPE studies sought to apply global South political ecology to urban studies of the global North. These studies drew attention to the unequal distribution of environmental benefits and burdens in the production of urban landscapes under capitalism. Like urban environmental historians, UPE scholars have argued that viewing cities as separate from nature is erroneous and harmful; it allows, for example, wilderness areas to be prized as pristine while pollution is seen as so endemic to urban working-class neighbourhoods that it is part of their identity, and, consequently, not adequately addressed. ${ }^{10}$ However, political ecologists and environmental historians now embrace the city as indispensable to their research. ${ }^{11}$ In addition, the city/nature binary must itself be subject to analysis, rather than an unquestioned assumption. Urban political ecologists recognize that all landscapes, from the 'pristine' wilderness to the bleakest industrial city, are composed of

recycling in Agbogbloshie-Accra: urban political ecology perspective', Local Environment, 23 (2018), 603-18.

${ }^{9}$ P. Robbins, Political Ecology: A Critical Introduction (Malden, MA, 2004), 12.

${ }^{10}$ For an overview of the development of UPE, see N. Heynen, 'Urban political ecology I: the urban century', Progress in Human Geography, 38 (2014), 598-604; N. Heynen, 'Urban political ecology II: the abolitionist century', Progress in Human Geography, 40 (2015), 839-45; N. Heynen et al., 'The enduring struggle for social justice and the city', Annals of the American Association of Geographers, 108 (2018), 301-16; H. Angelo and D. Wachsmuth, 'Urbanizing urban political ecology: a critique of methodological cityism', International Journal of Urban and Regional Research, 39 (2015), 16-27; C. Connolly, 'Urban political ecology beyond methodological cityism', International Journal of Urban and Regional Research, 43 (2019), 63-75.

${ }^{11}$ W. Cronon, Nature's Metropolis: Chicago and the Great West (New York, 1991); Heynen, Swyngedouw and Kaika, In the Nature of Cities. 
physical elements, transformed to a greater or lesser extent by humans, and of a set of socially constructed meanings and values: 'The world is a Cyborg world, partly natural and partly social, partly technical and partly cultural, but with no clear boundaries, centers, or margins.' ${ }^{\text {, }}$ The label 'natural' is one value which may be attached to a space, prescribing the accepted ways in which humans can interact with it as well its use as a metaphor, and what kinds of lessons we imagine can be learned from it. ${ }^{13}$

UPE research has tended to focus on present-day cities. However, its framework is also relevant to historical subjects, and studying earlier stages of urban growth can inform our understanding of the intersection between past and current issues. ${ }^{14}$ Historians thus have an important contribution to make to this lively interdisciplinary field. In addition, just as UPE scholars in other disciplines have deconstructed the city/nature binary as it affects urban life in the present day, historical analysis can examine how it was constructed. As the UPE framework has broadened, it has taken on the conceptual challenges and rewards of considering how people's race, gender and sexuality affect their access to and interactions with a range of urban ecologies that may promote or harm the health and wellbeing of humans and non-humans alike. ${ }^{15}$ Scholars have also called for UPE to return to its founding focus on the processes of urbanization rather than on urban spaces per se, bringing suburban, exurban or rural spaces into their analysis to understand the full scope of urbanization as a process. ${ }^{16}$ The issues and approaches of UPE are patently relevant to urban historians. ${ }^{17}$ Engaging with the field of UPE can enable interdisciplinary collaboration and offer useful ways to

\footnotetext{
${ }^{12}$ E. Swyngedouw, 'Impossible "sustainability" and the postpolitical condition', in R. Krueger and D. Gibbs (eds.), The Sustainable Development Paradox: Urban Political Economy in the United States and Europe (New York, 2007), 36.

${ }^{13}$ Gandy, Concrete and Clay; Swyngedouw and Kaika, 'Environment of the city'; Swyngedouw and Kaika, 'Urbanization of nature'; W. Cronon, 'The trouble with wilderness; or, getting back to the wrong nature', in W. Cronon (ed.), Uncommon Ground: Rethinking the Human Place in Nature (New York, 1995), 69-90; A. Rademacher, 'Urban political ecology', Annual Review of Anthropology, 44 (2015), 137-52.

${ }^{14}$ This point is made by Holifield and Schuelke, 'The place and time of the political in urban political ecology'; J. Mukherjee employs a 'historical urban political ecology' to understand Kolkata's relationship with water: Blue Infrastructures: Natural History, Political Ecology and Urban Development in Kolkata (Singapore, 2020); for an example of a non-historian using a political ecological framework for a historical subject, see M. Johnson, 'A political ecology of the medieval castle', Archaeological Papers of the American Anthropological Association, 29 (2018), 51-67.

${ }^{15}$ Heynen, 'Urban political ecology I'; Heynen, 'Urban political ecology II'; Heynen et al., 'The enduring struggle for social justice and the city', 301-16; Rademacher, 'Urban political ecology'; E. Goodling, 'Urban political ecology from below: producing a "peoples' history" of the Portland Harbor', Antipode, 53 (2021), 745-69; Y. Tzaninis et al., 'Moving urban political ecology beyond the "urbanization of nature"', Progress in Human Geography, 45 (2020), 229-52.

${ }^{16}$ Angelo and Wachsmuth, 'Urbanizing urban political ecology'; an approach used to great effect in one of the landmark works of urban environmental history: Cronon, Nature's Metropolis.

${ }^{17}$ Historical works that have addressed the indivisibility of the rural from the urban, as well as flows (of water and of waste, for example) in cities, include: Cronon, Nature's Metropolis; M. Dagenais, Montreal, City of Water: An Environmental History (Vancouver, 2017); J.A. Tarr, The Search for the Ultimate Sink: Urban Pollution in Historical Perspective (Akron, OH, 1996); M.V. Melosi, The Sanitary City: Environmental Services in Urban America from Colonial Times to the Present (Pittsburgh, 2008); T. Cooper, 'Peter Lund Simmonds and the political ecology of waste utilization in Victorian Britain', Technology and Culture, 52 (2011), 21-44.
} 
approach subjects of historical research. This article will add to the burgeoning UPE literature by providing a historical analysis of how ideas about nature and cities evolved in nineteenth-century London. As UPE perspectives would suggest, these ideas were intimately tied to the dominance and decline of laissez-faire political economy.

\section{Market forces as natural laws}

The system of classical, laissez-faire political economy developed during the Enlightenment, at a time when intellectuals were also striving to understand the laws of nature. Human society was likewise understood as functioning according to universal laws. Adam Smith famously described the price mechanism as an 'invisible hand' that allocated resources, capital and labour efficiently and enriched all who participated in the market. ${ }^{18}$ In popular nineteenth-century literature about political economy, market forces were described as 'natural'. In a work aimed at schoolchildren, Jane Marcet explained it thus:

Both the virtues and vices of mankind tend to destroy equality; the laborious, the intelligent, and skilful, will raise plentiful harvest; Nature thus rewards their exertions. The possessions of the idle, the careless, and the ignorant, will, on the contrary, gradually degenerate. Nature has annexed this penalty to their neglect. Shall we then counteract so wise a dispensation of Providence, by giving to the idle the reward of industry, and making the industrious bear a punishment due to the idle? ${ }^{19}$

Political economy was widely viewed not as a characteristic of a particular society at a particular moment, but as universally and eternally applicable. It was a 'dispensation of Providence', and as such, should not be counteracted. Even to imagine an alternative system was tantamount to blasphemy: 'It is dangerous to trust to your judgment when it leads you to conclusions so different from the established course of nature', the narrator chided her fictional interlocutor. ${ }^{20}$

In an age when many accepted that the principles of laissez-faire economics were as natural as the laws of gravity, established by a benevolent Providence for the good of humankind, the appearance of slums was troubling. Nobody had set out to produce the urban residential environments that had sprung up in response to industrialization. Slums formed when in-migrants crowded into buildings, often in back alleys, originally designed for much lower densities of habitation, or else when speculative builders put up working-class housing - often poorly built and densely packed, seldom provided with appropriate sanitary arrangements - on scraps and parcels of land close to industrial sites. Slums and their inhabitants seemed to appear like weeds without consent or invitation, and their very existence challenged laissez-faire orthodoxy. According to classical political economy, individuals

\footnotetext{
${ }^{18}$ A. Smith, An Inquiry into the Nature and Causes of the Wealth of Nations (1776) (London, 2001).

${ }^{19}$ J. Marcet, Conversations on Political Economy: In Which the Elements of That Science Are Familiarly Explained, 6th edn (London, 1827), 40.

${ }^{20}$ Ibid., 41.
} 
pursuing an increase in their personal wealth, interacting through the mechanism of the market, would raise the whole community's standard of living; Smith's 'invisible hand' was not supposed to create unhealthy, unpleasant spaces for urban workers that appeared even worse than the poor, rural homes they had fled. David Harvey has argued that cities are spaces in which the many positive and negative economic externalities that urban activities produce make it impossible for market forces to allocate resources efficiently. ${ }^{21}$ During the second half of the nineteenth century, as efforts to fix the slums by reintegrating them into a rational, free-market system repeatedly foundered, the failure of these spaces to conform to 'natural' market forces made them appear unnatural.

Understanding the multifarious and overlapping meanings of the words 'nature' and 'natural' is important for those who study Victorian cities, for the terms were deployed in the service of agendas and ideologies and had implications for the lives of marginalized groups. These ideologies operated in a particular political-economic context, interacting at various scales with humans' daily lives, needs, ambitions and constraints, to produce a variety of urban landscapes, from the 'de-natured' industrial districts and slums to the 'natural' parks and open spaces that seemed to provide an antidote to urban ills. In turn, these spaces reproduced the existing political order, but could also challenge it, calling forth reforming discourses and activities, and necessitating new institutional forms. Deconstructing ideas of nature and their intersections with capitalist political economy sheds light on the paradoxes inherent in Victorian slums.

\section{Air, water, sunlight and market principles: George Godwin and the model dwelling companies}

In the 1840s, reformers led a first offensive against slum housing. Slums were not yet understood as artificial. Nature was all too present there in its old, threatening form, where diseases stalked the urban courts as wolves had once stalked England's forests. ${ }^{22}$ These diseases were believed to be spread by miasmas, which came above all from decaying organic material; this kind of nature needed to be banished, and what remained - including the working people who lived there - set in order. Influenced by the cholera and typhus epidemics of the 1830s, as well as anxieties over social issues such as urban crime and the working-class Chartist movement, reformers promoted solutions that deployed natural resources, including sunlight, clean water and fresh air, as well as financing models carefully crafted to conform to free-market principles.

For the influential political economist John Stuart Mill, nature was an important factor in political economy. Access to natural resources such as fertile land, pleasant climate or coal and metal ores explained in part the relative wealth and poverty of

\footnotetext{
${ }^{21}$ D. Harvey, Social Justice and the City (Athens, GA, 2009).

${ }^{22}$ In fact, as Elizabeth Baigent has shown, working-class housing was teeming with all kinds of nonhuman life, some useful, some detrimental to inhabitants, which, however, 'did not disrupt the narrative that poor people lacked nature': 'Octavia Hill, nature and open space: crowning success or campaigning "utterly without result"', in E. Baigent and B. Cowell (eds.), 'Nobler Imaginings and Mightier Struggles': Octavia Hill and the Remaking of British Society (London, 2016), 142-6.
} 
nations. ${ }^{23}$ Mill followed Enlightenment thinkers in viewing nature as 'external' to humans, and, consequently, available to meet human needs. ${ }^{24}$ He lauded humanity's achievement in using the knowledge of nature to bring its powers under human control, for the benefit of all. 'The legitimate employment of the human faculties', he stated, was 'that of compelling the powers of nature to be more and more subservient to physical and moral good. ${ }^{25}$

Like Mill, the architect and editor George Godwin (1813-88) viewed nature as a set of resources available to humans to control and use for their benefit. In common with sanitary reformers of the time, his writing highlighted three specific resources pure air, clean water and sunlight - and he argued that houses well-supplied with these would enhance their inhabitants' physical and moral well-being. Homes were degraded, dangerous and even 'unnatural' when they were cut off from the flow of these resources. He described the 'unnatural gloom' of basement dwellings, and the misery of those who were "born and die[d] in these underground dens, into which a ray of sunlight c[ould] scarcely struggle', lacking 'light, that necessary of life, ${ }^{26}$

Godwin helped to create a public discourse about the inadequacies of workingclass housing in London and to recommend remedies. As editor of The Builder, 'the most important and successful professional paper of its kind', from 1844 to 1883 , Godwin publicized various social causes, and promoted philanthropic societies that planned and built model dwellings for workers and artisans. ${ }^{27}$ Godwin's adherence to the laissez-faire consensus had helped to make The Builder a success after a shaky start: the journal's first two editors had been Owenite socialists and under their direction circulation had been poor. ${ }^{28} \mathrm{He}$ aimed to improve building practices through elevating the status of the architectural profession and stimulating interest in philanthropic capitalism, without challenging the tenets of liberalism. In the 1850s and 1860 s, he published a series of extended pamphlets based on his personal observations of poor districts of London, in an effort to raise public awareness of bad living conditions and the disastrous consequences that threatened to ensue.

Godwin was not the first to write about what he termed 'the "Homes" of the Thousands'. ${ }^{29}$ Public discourse on sanitary conditions in the 1840 s had inevitably touched on housing. The novelist Charles Dickens and the journalist Henry Mayhew had portrayed the lives, attitudes and neighbourhoods of London's poor in ways that garnered public attention, and the 1850s saw an outpouring of

\footnotetext{
${ }^{23}$ J.S. Mill, Principles of Political Economy, with Some of Their Applications to Social Philosophy (1848), ed. W.J. Ashley (London, 1909), 102-7.

${ }^{24} I$ Ibid., 39. Previously, humankind had been seen as part of God's creation; having a privileged role within it, certainly, but not separate from it: R. Williams, Problems in Materialism and Culture: Selected Essays (London, 1980), 75-7, 79.

${ }^{25}$ Mill, Principles, 979.

${ }^{26}$ G. Godwin, Town Swamps and Social Bridges (London, 1859), 13, 18.

${ }^{27}$ G.B. Smith, R. Richardson and R. Thorne, 'Godwin, George (1813-1888), architect and journal editor', 2004, www.oxforddnb.com/view/10.1093/ref:odnb/9780198614128.001.0001/odnb-9780198614128-e-10891, last accessed 4 Nov. 2020; see also J. Winter, Secure from Rash Assault: Sustaining the Victorian Environment (Berkeley, 1999), 196-204.

${ }^{28} \mathrm{R}$. Thorne, 'Building bridges: George Godwin and architectural journalism', in G. Marsden (ed.), Victorian Values: Personalities and Perspectives in Nineteenth-Century Society (London, 1990).

${ }^{29} \mathrm{G}$. Godwin, London Shadows: A Glance at the 'Homes' of the Thousands (London, 1854).
} 
works on the same theme, amongst which were Godwin's. ${ }^{30}$ What set Godwin's theme apart was its focus - suited to an architect - on the buildings in which the poor lived and the effects of these degraded environments on their inhabitants. If his tone shared some of the prevalent sensationalism, his aim was to do more than shock. He wrote to garner support for the model dwelling companies, such as the Peabody Trust and the Society for Improving the Condition of the Labouring Classes, and he frequently referred to their buildings as havens of health in the midst of the slums.

Godwin shared the accepted view that housing for the working classes should be provided by private means and on a commercial basis. The problem seemed to be that speculative builders, as well as landlords who allowed overcrowding in older houses, were making excessive profits from the poor while unscrupulously neglecting their duty to build sound homes or to maintain them in habitable condition. If honest men could build houses that conformed to sound architectural and sanitary standards and rent them out at a modest profit, then other investors would follow their example. At the same time, the working-class renters would surely choose the healthier, more attractive dwellings if the cost were not too high. The four decades after the repeal of the Corn Laws in 1846 were the 'high tide of laissez-faire' and it was widely believed that the market could and would improve the conditions of all classes if allowed to operate without interference. ${ }^{31}$

Godwin admitted that 'pure high-soul'd unselfishness' was one motivation for trying to relieve the distress of those living in such deplorable conditions. ${ }^{32}$ But he argued that the commercial spirit was an even more powerful inducement. Invoking the fear that disease could spread, as it had in the cholera epidemics of 1832 and after, to all sectors of the city, as well as the financial cost of dealing with criminals, he argued that investment in better housing was common sense and would not contravene laissez-faire principles:

It must not be supposed that we seek, by these papers on the dwellings of the London poor, to awaken sympathy in behalf of individuals, to be expressed by pecuniary assistance to them. Our object, it must be evident to all who will give it any consideration, is permanent improvement and general amelioration. We would show the great want there is of decent accommodation for the poorer classes, the miserable state in which thousands are lodged, the degrading and demoralizing effect of this upon the character; and then point to the fact that decent accommodation may be provided for them, and a fair return be obtained for the money laid out in effecting it, to say nothing of the sums that would be saved to the community by the diminution of crime, disease, and death (not confined, let it be remembered, to the locality of the originating hovels), to which such improvements would unquestionably lead. ${ }^{33}$

\footnotetext{
${ }^{30} \mathrm{G}$. Himmelfarb, The Idea of Poverty: England in the Early Industrial Age (New York, 1984), 355.

${ }^{31}$ S. Gordon, 'The London Economist and the high tide of laissez faire', Journal of Political Economy, 63 (1955), 461-88.

${ }^{32}$ Godwin, Town Swamps, vi.

${ }^{33}$ Godwin, London Shadows, 13.
} 
The 'fair return' that Godwin referred to was usually agreed upon at 5 per cent; in fact, the model housing societies and similar initiatives were often known as 'philanthropy and five per cent'. ${ }^{34}$ In some cases, such as Octavia Hill's housing projects, any profit over 5 per cent was to be reinvested in improvements to the apartments themselves. Housing activists believed that insisting upon keeping the investment profitable would achieve a number of benefits. First, other investors would be persuaded that they could make an honest profit, and this incentive would ensure a supply of appropriate housing to match demand. Second, renters could retain the dignity of possessing a valid contract rather than being reduced to dependence on hand-outs; this would help them retain a respectable and productive work ethic and discourage idleness. Finally, housing provided within the market mechanism would discourage more migrants from coming to cities than the job opportunities warranted.

Such arguments undoubtedly show sensitivity towards the working classes and their self-respect. Reformers like Godwin expressed genuine compassion for those forced to live in homes that endangered their health and livelihoods. They regarded the poor not as superfluous but as an integral part of the national economy. They believed that the interests of rich and poor were compatible. If all classes worked to improve their own conditions, the national wealth would increase and all would benefit.

Yet Godwin and like-minded reformers refused to acknowledge that the market was not, on its own, meeting the needs of the poor. Wages were simply too low for most urban workers to afford housing that met either their own standards or those the middle and upper classes assigned to them. The truth was that even those societies that paid their 5 per cent dividends - and this itself, since it was considerably lower than other available investment opportunities, may be considered a market-distorting subsidy - never did so under perfect market conditions. They bought land at below-market value, since the law required that it be used for working-class housing to replace demolished slums, rather than any more lucrative use. In addition, the government often provided low-interest loans for the housing societies. ${ }^{35}$ These subsidies were hidden and the societies touted as examples of philanthropic capitalism. In this way, the free market could be portrayed as more efficient than it actually was, more radical critiques could be diverted and the unscrupulous builder or landlord labelled the villain of the piece.

Although Godwin wanted natural forces such as flowing water, sunlight or naturalized free markets to drive out dirt, disease and disorder, he consistently described non-human life in the slums as out of place. The sky could be seen through holes in the roof of a room whose only greenery was the mildew on the walls; vegetables were stored under beds, and rabbits shared living space with overcrowded families. Even cattle kept in urban dairies were unhappy and unhealthy,

\footnotetext{
${ }^{34}$ A.S. Wohl, The Eternal Slum: Housing and Social Policy in Victorian London (Montreal, 1977); J.N. Tarn, Five Per Cent Philanthropy: An Account of Housing in Urban Areas between 1840 and 1914 (London, 1973); G. Himmelfarb, Poverty and Compassion: The Moral Imagination of the Late Victorians (New York, 1991).

${ }^{35}$ Wohl, The Eternal Slum; Himmelfarb, Poverty and Compassion.
} 
breathing polluted air and providing poor-quality milk. ${ }^{36}$ These forms of non-human nature in the city were portrayed as corrupted and degraded by human activity.

As a professional architect, Godwin could claim to be qualified to evaluate the buildings in which the poor lived. In between other duties, he made time to go into slum areas and describe the conditions he saw. These back alleys were hidden from the middle-class gaze. Godwin likened himself to an intrepid colonial explorer, making visible through his efforts and his qualified architectural eye the diseased parts of the urban body: 'To investigate the houses of the very poor in this metropolis is a task of no small danger and difficulty: it is necessary to brave the risks of fever and other injuries to health. ${ }^{37}$

Because his professional training conditioned him to pay attention to buildings, Godwin's narrative began with the actual fabric of the houses, their disrepair, their situation and their amenities. He saw buildings before he saw people. When he moved on to describe the inhabitants, they seemed to be as much a part of the decor as the rotting wallpaper or the meagre furniture. The buildings, by shaping and constraining family life and physical health, produced the working classes. Godwin cautioned his readers not to judge the poor: not only their physical, but their moral state was determined, he asserted, by the spaces in which they lived, in a process he described with a natural metaphor: 'The child was small, drooping, and bleached, like many of the plants which attempt to vegetate in such places. ${ }^{38}$

Godwin presented both the market and the urban processes by which unhealthy spaces produced unhealthy people as natural forces or laws which it was useless to resist. But in working to relieve the environmental burdens that limited their ability to thrive, rather than restoring working people's agency, reformers imposed their own solutions. One criticism levied at the model dwellings was that the only benefit they conferred was sanitary. The only natural resources they aimed to recapture for the poor were fresh air, clean water and sunlight, admittedly crucial for life and conferring a significant improvement on the reeking courts Godwin described in his writing. But the necessity of continuing to provide a dividend to shareholders, and thus avoid explicit critique of liberalism, meant that blocks were built high to maximize the use of expensive land, all superfluous architectural embellishment was abandoned to reduce building expenses and there was very little open space, let alone any gardens, trees or green grass around the buildings. ${ }^{39}$ Some complained that the model dwellings resembled barracks or prisons. ${ }^{40}$

By allowing the exigencies of profit to define which natural elements could be used to reform the slums, Godwin limited solutions to those 'already prefigured by the way in which Nature [was] made to speak'. ${ }^{41}$ If the inhabitants were less affected by environmental 'bads' than those who remained in the slums, they did

\footnotetext{
${ }^{36}$ Godwin, London Shadows, 5, 3; G. Godwin, Another Blow for Life... (London, 1864), 37; Godwin, Town Swamps, 12-14.

${ }^{37}$ Godwin, London Shadows, 1.

${ }^{38}$ Ibid., 6.

${ }^{39}$ Tarn, Five Per Cent Philanthropy.

${ }^{40} \mathrm{G}$. Stedman Jones, Outcast London: A Study in the Relationship between Classes in Victorian Society (Oxford, 1971).

${ }^{41}$ Swyngedouw, 'Impossible "sustainability", 21.
} 
not have access to the environmental 'goods' that public parks and private squares provided in upper- and middle-class neighbourhoods. It was reformer Octavia Hill who, beginning in the 1860s, would begin efforts to remedy this situation and to redefine what elements and ideas of nature belonged in working-class urban districts.

\section{Flowers in the heart of the slum: Octavia Hill}

This new wave of housing reform relied upon a new argument about the ways working-class people might interact with nature: not only by benefiting from material resources, but by appreciating 'natural' spaces for their aesthetic appeal and psychological benefits. If Octavia Hill, the pioneer of this view, still expected housing provision to conform strictly to market forces, she viewed urban green spaces as subject rather to non-capitalist modes of ownership.

From the very beginning of her philanthropic career, Octavia Hill (1838-1912) strove to reconnect working-class Londoners with nature. As a teenager, supervising impoverished girls in a toy-making co-operative, she brought her employees on nature walks, teaching them the names of flowers. In her work to provide better housing for the poor in London, she endeavoured to provide greenery, open spaces and, where possible, gardens in her courts. The National Trust, which she co-founded, still works to preserve natural and historic spaces for the enjoyment of the public.

Hill came from a middle-class family that had suffered severe financial difficulties after the bankruptcy and mental breakdown of her father when she was three years old. Her mother, Caroline, brought up five daughters in a rural setting with support from her own father, the sanitary reformer Dr Thomas Southwood Smith, until Octavia (the middle child) was 13; then she moved her family to London to find jobs for herself and her older daughters. They took on various roles in a philanthropic co-operative. This contravened no gender or class norms: although it was unusual for middle-class women to work outside the home, the Hills' paid employment was similar to the kinds of voluntary activities in which affluent women could respectably engage. As supervisors and administrators, they upheld their place in the class hierarchy. But the Hills, mother and daughters, were engaged in charitable work not only from financial need, but also from deeply held conviction, as Octavia's later career would demonstrate.

While she was still in her teens, Octavia's work and her artistic talent brought her into contact with John Ruskin, the influential art critic, writer on social issues and 'great thunderer'. ${ }^{42}$ Ruskin's emphasis on nature as a source of truth and beauty influenced Hill. He also shared her concern for the poor. In 1864, they embarked together on a project to provide improved housing in a poor area of London. He bought a group of houses inhabited by 'low' people, and Hill managed the properties, collecting rent and effecting repairs, while guaranteeing a return of 5 per cent on his investment. ${ }^{43}$

\footnotetext{
${ }^{42}$ M.J. Wiener, English Culture and the Decline of the Industrial Spirit, 1850-1980 (Cambridge, 1981), 37.

${ }^{43} \mathrm{O}$. Hill, 'Organized work among the poor: suggestions founded on four years' management of a London court', Macmillan's Magazine, 20 (1869), 220-1.
} 
Hill's concept of nature, heavily influenced by Ruskin's, had much in common with the values of William Morris, Raymond Unwin and others in the Arts and Crafts movement, although unlike Morris and Unwin she was unsympathetic towards socialism. Unlike American conservationists such as John Muir who valued the untouched wilderness, Hill viewed nature as an inhabited space. She drew on a tradition of conservative anti-capitalism that viewed the true essence of Englishness as pastoral, not urban. ${ }^{44}$ She remained deeply attached to the principle of self-help, believing that philanthropic work could not contravene the laws of political economy or it would 'demoralize' the poor, causing them to devalue labour and rely on handouts. ${ }^{45}$

This faith in the laws of political economy, particularly that of supply and demand in urban housing and labour markets, is evident in the testimony she gave before the 1884 Royal Commission on the Housing of the Working Classes. ${ }^{46}$ Hill, the only woman called to give evidence, revealed in extensive testimony her conception of how such markets worked. Although she felt that the authorities should intervene on sanitary grounds if too many tenants crowded into a single room, she refused to countenance any action to limit rent increases. Rather, authorities should let the natural working of supply and demand play out. When asked whether a landlord should increase rent if he could get it, she replied, 'I should have thought so, and that the natural tendency of that would have been for wages to rise in proportion if the cost of living rises.' Such a process may have seemed 'natural', but it did not reflect actual conditions. Wages were not keeping pace with rent increases, and Hill's only suggestion was that 'something more efficient must be done. People must emigrate, for instance. ${ }^{47}$ This solution itself existed in the context of colonization, which also depended on presenting processes driven by a multiplicity of individual human decisions as the product of natural laws. Explaining the subjugation, expropriation and even extermination of 'savage' peoples as processes of natural selection obscured and exculpated the actions of imperial governments and colonial settlers. While Hill did not rely on violence to bring order to the slums, her justification of crushing rent increases as a natural and thus morally neutral process paralleled the rhetorical moves of imperial apologists.

Hill did not usually have housing built specifically for her tenants. ${ }^{48}$ Instead, she took over the management of existing, run-down houses. She had them cleaned and repaired, and made it clear to the tenants that if they did not damage the buildings or fixtures, their rent money could go towards improving their amenities rather than repairing them. Unlike Godwin, Hill believed that transferring people out of urban spaces of degradation into sanitary buildings would achieve nothing.

\footnotetext{
${ }^{44}$ Wiener, English Culture; R. Williams, The Country and the City (New York, 1973); Baigent, 'Hill, nature, and open space'.

${ }^{45}$ Hill, 'Organized work', 219-26; Himmelfarb, Poverty and Compassion; Stedman Jones, Outcast London.

${ }^{46}$ George Godwin was appointed one of the commissioners.

${ }^{47}$ First Report of Her Majesty's Commissioners for Inquiring into the Housing of the Working Classes (London, 1885), 305.

${ }^{48}$ The cottages on Red Cross Way are an exception, designed by the architect Elijah Hoole to Hill's specifications, and opened in 1887.
} 
What was needed was for the poor themselves to be transformed along with their dwellings. Weekly rent collection was more than a financial transaction. Hill and her small army of volunteers used the opportunity to enter the homes of the tenants and use their influence to encourage values that they deemed respectable. Tenants who paid rent on time and conformed to certain rules of conduct such as sending children to school - were rewarded with homes that, although old and small, were kept clean and sanitary, and when money was available, provided with extra amenities such as washing facilities or playgrounds. ${ }^{49}$

All this reveals a level of surveillance and discipline that must have seemed irksome to some of her tenants. Hill also failed to understand the exigencies of casual employment, and the informal strategies casual and seasonal labourers used to get through the slack season. For example, getting behind on the rent in winter and then paying the arrears when the jobs opened up again in spring was an economic strategy that Hill rejected entirely as a simple failure to plan ahead or to apply selfcontrol to spending in good times - and thus a moral failing. ${ }^{50}$ Worse, it was unjust to those tenants who did pay on time: 'I had been informed that the honest habitually pay for the dishonest, the owner relying upon their payments to compensate for all losses. ${ }^{51}$ Still, she reached a poorer group of Londoners than did the model dwellings, and her houses seldom had vacancies; her attitude was certainly condescending, but it evidently fit the material and cultural aspirations of a certain stratum of London's working classes. ${ }^{52}$

The deliberate exclusion (by eviction) of those who refused to abide by a set of rules of conduct established, not by mutual consent, but by Hill herself, made her schemes appear highly successful, even though they could never solve the housing problem except for her chosen tenants. Another reason for her success was the emphasis she placed on knowing her tenants personally. Hill had contacts among potential employers - especially middle-class families requiring domestic servants - and knew how important a personal reference was for them. She felt that charitable gifts, when absolutely necessary, should be given personally by a landlady who is also a 'friend' rather than by an impersonal organization. In addition, many of her tenants recognized the 'deep and silent under-current of sympathy' that lay beneath the 'rebuke and repression' she felt necessary to keep her 'well-controlled little regiment' in line, and responded with co-operation. ${ }^{53}$

Hill worked especially hard to provide her tenants access to nature, in the form of open or green space, gardens, trips to the country or providing cut flowers. As London continued to grow in the 1870s and land prices rose, she observed that fields and heaths within the city's boundaries were being sold and covered in new residential developments. Working closely with the poor, she was keenly aware of the value of publicly accessible natural spaces. Her campaign for open spaces laid the groundwork for the foundation of the National Trust in 1895. In

\footnotetext{
${ }^{49}$ Hill, 'Organized work', 220.

${ }^{50}$ Stedman Jones, Outcast London.

${ }^{51}$ Hill, 'Organized work', 220.

${ }^{52}$ For one family of tenants, living in one of Hill's properties was a stepping stone towards social mobility for the subsequent generations, as their descendant details in his family history: D.A. Rose, Octavia's People - The Story of the Pearce Family at Redcross Cottages, Southwark (Wisbech, n.d.).

${ }^{53}$ Hill, 'Organized work', 224.
} 
one of her first projects in Freshwater Place, she instituted a playground festival in May which included a 'May-pole or a throne covered with flowers for the May-queen and her attendants'. 54 One historian thought this scene 'ludicrous', but it speaks of Hill's commitment to reconciling city and nature to purify the slums. ${ }^{55}$ Hill's concept of nature drew from the culture of pre-industrial rural life. Bringing nature to the slums meant importing not only the flowers themselves, but traditions and customs associated with the English countryside. ${ }^{56}$

If others of her class tended to view working-class districts as devoid of nature because the nature that existed there served for labour and production rather than leisure and aesthetic pleasure, Octavia Hill differed in viewing natural spaces as places where labour could be performed. She saw nothing wrong with using neighbourhood playgrounds to hang washing when children were in school, for example. ${ }^{57}$ In contrast, George Godwin had critiqued the presence of non-human life in residential spaces when it was used for work. He disapproved of costermongers storing their produce overnight in their rooms, but presented Huguenot weavers who grew flowers around their homes as respectable. ${ }^{58}$

Despite her insistence on applying the principles of classical economy in her housing work, some of Hill's articles on open spaces contain an implied critique of the effects of land commodification. ${ }^{59}$ In an 1877 article on the need for regulation and surveillance to prevent too many open spaces being enclosed for agriculture or development, she noted that the right to 'wander freely, and to enjoy the beauty of earth and sky' had no established money value, and as such was vulnerable to loss if the market alone was allowed to regulate land use and rights. ${ }^{60}$ She recognized that use-value could be worth more than exchange-value: 'Is it not strange to take away free enjoyment from many, and to offer in exchange, at any money payment, a privilege to the few? ${ }^{61}$ In cases where enclosure was happening informally, with no act of parliament to regulate it, Hill called attention to the fact that although the poor who held certain rights over the commons were being compensated for the loss - for example by receiving an allowance of coal instead of the right to collect firewood - the payment might not be equivalent, and more importantly, the rights had become gifts, which 'depend often on the will of squire or lord... and become a form of dole instead of a birthright'. ${ }^{62}$ Hill objected strongly to the state (national or municipal) purchasing the land; the best way to protect open space, she argued, was to uphold commoners' traditional rights.

\footnotetext{
${ }^{54} I b i d ., 221$.

${ }^{55}$ The scene reads as ludicrous in part because it represented a middle-class reformer's view of rural English traditions rather than the residents' own initiative; but also, surely, because the city/nature binary made traditional rural practices appear unsuited to an urban space: Wohl, The Eternal Slum. 'Sites are enacted through practices, which are not spatially bound': Connolly, 'Urban political ecology beyond methodological cityism', 64.

${ }^{56}$ Hill's notions of Englishness and their relationship to her views of nature are discussed in Baigent, 'Hill, nature, and open space'.

${ }^{57}$ Baigent, 'Hill, nature, and open space', 146-7.

${ }^{58}$ Godwin, London Shadows, 3, 33.

${ }^{59}$ Baigent, 'Hill, nature, and open space'.

${ }^{60}$ O. Hill, Our Common Land (and Other Short Essays) (London, 1877), 631.

${ }^{61}$ Ibid., 637.

${ }^{62}$ Ibid., 637.
} 
How could Octavia Hill be so passionate in her call for government regulation of open spaces, yet so adamant that only the market should regulate the allocation of housing in cities? There were tensions also between her commitment to the tenets of capitalist political economy, and her adherence to the idea of commoners' rights, a survival from the feudal economic system. Her notions of nature allowed her to bridge the two contradictory positions, obscuring the tensions between the laissezfaire liberalism she professed and her calls for some regulation of the market in favour of the poor. She viewed the free market in housing as a kind of natural, selfregulating system, which would only be thrown off balance by government intervention. At the same time, she aspired to an image of pre-industrial, rural England, where people lived in direct, everyday contact with nature; a society where people knew both each other, and their own place in the hierarchy, appeared natural by extension. This complex, contradictory concept of nature allowed Hill to critique enclosing landowners as greedy land-grabbers while at the same time exhorting London labourers to submit to the rational exigencies of the labour market and eschew those strategies that did not conform to it.

\section{'Unwalled roses in the streets': Henrietta Barnett}

By the end of the century, the persistence of slum dwellings in the capital, despite multiple attempts to cure their ills by applying market discipline, led municipal authorities to step in. The London County Council built its first housing projects in the 1890s, and subsequently local government would become the primary provider of social housing, allowing many working-class families to escape the physical and psychological stresses of slum living. Yet to a new generation of reformers, these homes, although sanitary and respectable, still failed to reconnect their residents with the physical and moral benefits of nature.

If Octavia Hill focused her efforts on working-class housing, her protégée Henrietta Barnett envisioned urban spaces that would bring together all classes in a green and pleasant residential suburb. Barnett began her career as a volunteer rent-collector in Hill's organization. She and her husband were friends and fervent admirers of Hill and although they eventually diverged in their priorities, ideas and practices, her influence remained evident in everything the Barnetts did.

Henrietta had grown up in an affluent family, but had become disillusioned with what she saw as the selfish pleasure-seeking of the middle classes while millions lived in poverty. When she married Samuel Barnett, a clergyman, in 1873, they took the parish of St Jude's in Whitechapel, one of the most notorious East End slums (they were still serving there in the 1880s when Jack the Ripper committed the infamous Whitechapel murders). Living and working among the poor gave the Barnetts some insight into their lives; their deeper understanding of the working classes contrasts with Godwin's (albeit sympathetic) fact-finding adventures.

Henrietta and Samuel immersed themselves in the task of providing both social and spiritual improvements in the lives of their parishioners, using their first-hand knowledge to challenge prevailing opinions about the poor and their problems. Henrietta, for example, wrote in an 1866 article of Mrs Marshall, a widow who supported her family on nine shillings a week: 'And how do the rich look on these facts? "Well, nine shillings a week is very fair wage for an unskilled working 
woman", was the remark I heard', Henrietta reported, noting that this was the cost of wine at one meal for the speaker. Her article listed in detail the amount of food needed to nourish a family adequately, as well as rent and other costs, which came to more than Mrs Marshall's wages, thus proving the rich man's opinion callous and ungrounded in fact. ${ }^{63}$

The Barnetts were alarmed at the geographical separation between wealthy and poor districts in London, believing this was the root cause of social problems. If the rich knew the poor better, they argued, they would not form callous and ungrounded opinions. If the rich and poor lived in the same neighbourhood, the rich would never allow such squalor to exist. In 1884, the couple founded Toynbee Hall, a settlement house where Oxford undergraduates could stay for extended periods to live among the poor, while offering university extension classes on diverse subjects. Although Toynbee Hall did produce a number of influential political leaders, Henrietta came to see it as no more than 'an artificial protest against the massing in one locality of the poor ${ }^{64}$ In 1908, after several years of capital-raising, organizing and publicizing, work was begun on the Hampstead Garden Suburb, Henrietta's best-known legacy. Here, she hoped, rich and poor would live together in one neighbourhood, connected to each other and to nature, in a planned community.

Henrietta Barnett believed that separation of the classes resulted from the real estate market, as overcrowded neighbourhoods became less desirable for those who could afford to live elsewhere. Barnett's critique of council housing was not that the municipality should never be involved in the housing market; here she differed from Hill's strongly held objection to such intervention. The problem, for Barnett, was that councils built ugly, uniform housing, 'limiting a neighbourhood entirely to persons of one social class' ${ }^{65}$

Unlike Hill or Godwin, then, Barnett did not view market forces as universal laws; rather, they reflected the values and relationships of the persons who transacted with each other in those markets. It was 'the landlord's greed, the builder's competition, and the people's helplessness', she wrote, that had produced these socially and aesthetically sterile spaces ${ }^{66}$ Barnett harkened back to an imagined English rural life in which people of all classes lived in sympathy and relative harmony precisely because they were not segregated into homogeneous urban spaces. She viewed existing urban neighbourhoods as artificial and envisioned solutions rooted in her ideas of nature. However, in Barnett's conception, it was the unspoilt beauty of Hampstead Heath and the artfully designed suburb attached to it, combined with sympathetic relations between residents of all classes, that would underpin the housing market so that it would no longer produce slums or class-segregated neighbourhoods. Rather than the market as a natural force that would shape and discipline both spaces and people, in Barnett's view it was the

\footnotetext{
${ }^{63}$ S.A. Barnett and H. Barnett, Practicable Socialism: Essays on Social Reform (London, 1888), 9-10, http://archive.org/details/practicablesoci00barnuoft, last accessed 9 Jan. 2019. The Barnetts, despite the title of this work, were not socialists; they believed socialism was in fact impracticable and suggested more moderate reforms.

${ }^{64} \mathrm{H}$. Barnett, 'A Garden Suburb at Hampstead', Contemporary Review, 87 (1905), 234.

${ }^{65}$ Ibid., 234.

${ }^{66}$ Ibid., 231.
} 
natural space that would shape social relations, and these relations would be reflected in the housing market.

In the Hampstead Garden Suburb, land was owned on a co-operative basis. Barnett and the other trustees of the development offered a small (5 per cent) but safe return on capital invested. Any profit earned beyond this limit would be either reinvested into amenities and repairs, or paid in dividends to the renters themselves. Most renters would be paying ground rent only, having had a house built at their own expense; some of the working-class residents would be renting the cottage itself. The community would thus be motivated to keep the neighbourhood clean and attractive, knowing they themselves would benefit both materially and financially. ${ }^{67}$ This is an obvious development of Octavia Hill's basic idea; however, here, it was applied to both rich and poor residents and thus lost some of its disciplinary character.

The suburb was and is administered by the Hampstead Garden Suburb Trust, of which Henrietta Barnett was the secretary and driving force. Parliament passed the Hampstead Garden Suburb Act in 1906, allowing the principal architect, Raymond Unwin, to plan the suburb according to a vision inspired by Ebenezer Howard's Garden Cities, as well as by the Arts and Crafts movement, with its attachment to traditional building materials, medieval architectural forms, and harmony with the natural surroundings. The plan ensured that no building blocked another's view of Hampstead Heath. Buildings were often grouped around a small communal green space, and every home had a small garden. These gardens were crucial to the vision of harmonious living in the suburb, providing a 'common interest' that would break down misunderstanding between classes: 'The common interest in the Garden Suburb will be the time-honoured one of a garden, and the love of flowers and fruits and growing changing things. ${ }^{68}$

The gardens would offer other advantages to the working-class residents. It was expected that the men would produce food (while children helped and wives watched), earning a financial and physical benefit. Barnett had previously written about her concerns over the working-class diet. ${ }^{69}$ Over and above the physical benefits of the garden were its moral effects: by encouraging family bonds and an interest in nature, it represented 'the best security against the temptations of drink and gambling. ${ }^{70}$

Barnett was careful to inform her potential supporters that her scheme would be run on 'a financial basis', even though her description of the amenities offered to the poor, elderly and disabled might convince readers that 'the scheme is one for philanthropic effort'. ${ }^{71}$ An elegantly illustrated volume, Town Planning and Modern Architecture at the Hampstead Garden Suburb, similarly emphasized not only the homes' beauty and comfort, but the way in which the development of the whole suburb at once according to a unified plan allowed economies of scale,

\footnotetext{
${ }^{67}$ H. Barnett, 'Science and city suburbs', in J.E. Hand (ed.), Science in Public Affairs (London, 1906), 67-8.

${ }^{68}$ Barnett, 'Science and city suburbs', 63.

${ }^{69}$ A. Creedon, 'Only a Woman', Henrietta Barnett: Social Reformer and Founder of Hampstead Garden Suburb (Chichester, 2006), 28.

${ }^{70}$ Barnett, 'Science and city suburbs', 57.

${ }^{71}$ Ibid., 71.
} 
so that good-quality housing could be constructed at a lower cost than a speculative builder could offer. ${ }^{72}$

However, a century later, the Hampstead Garden Suburb, although beautiful, is no longer the embodiment of Henrietta Barnett's vision. It has, 'through the workings of the property market, inevitably become a wealthy community, with many of the smaller artisans' cottages now supporting ownership of two or three cars' ${ }^{73}$ It is 'a middle-class enclave whose residents wish more to preserve their standards of taste, comfort and privacy than to promote Henrietta's dream that all classes of society should enjoy the benefits of education, leisure and social opportunities in a beautiful and healthy environment'. ${ }^{74}$ The co-operative landownership model broke down under the rampant inflation of World War I and its aftermath. Like other housing reformers, Henrietta Barnett had worked hard to integrate the power of capitalism into a scheme whose heart was social harmony. But it was the market itself, in the end, that destroyed the dream for which she had striven.

\section{Conclusion}

Nature is 'perhaps the most complex word in the language'. ${ }^{75}$ Because its meaning appears self-evident, it may contain multiple, even contradictory significations; as we have argued here, the term is never devoid of political content, and its apparent transcendence of human concerns can be used to obscure the power relations that maintain inequality.

We have used a historical urban political ecology - cross-fertilizing urban environmental history and urban political ecology - as a guiding framework to examine the discursive and material conditions that go into the production of uneven urban landscapes. ${ }^{76}$ A historical perspective is central to disentangling the socio-ecological relations that bring about uneven urban environments. To this end, UPE scholars have shown how such environments are produced in a context of unequal sociopower relationships and involve flows of capital and ecological resources in ways that challenge "understandings of "cities" as ontological entities separate from "nature". 77 Accordingly, focusing on contemporary urban social-environmental realities, often produced within the broader dynamics of the neoliberal political economy, urban political ecologists have done much to politicize urban socioenvironmental transformations, pointing to the associated unequal distribution of costs and benefits. ${ }^{78}$ In this article, therefore, we sought to demonstrate how examining the nexus of power, inequality and material and discursive control over

\footnotetext{
${ }^{72}$ R. Unwin and M.H. Baillie Scott, Town Planning and Modern Architecture at the Hampstead Garden Suburb (London, 1909).

${ }^{73}$ M. Miller, 'The saga of the "suburb salubrious", Planning History, 14 (1992), 4-12.

${ }^{74}$ K.M. Slack, Henrietta's Dream: A Chronicle of the Hampstead Garden Suburb 1905-1982 (London, 1982), 116.

${ }^{75}$ R. Williams, Keywords: A Vocabulary of Culture and Society (New York, 1976), 184.

${ }^{76}$ Mukherjee, Blue Infrastructures.

${ }^{77}$ Tzaninis et al., 'Moving urban political ecology beyond the "urbanization of nature"'.

${ }^{78}$ See, e.g., P. Gibas and I. Boumová, 'The urbanization of nature in a (post)socialist metropolis: an urban political ecology of allotment gardening', International Journal of Urban and Regional Research, 44 (2020), 18-37; D. Harvey, A Brief History of Neoliberalism (Oxford, 2005).
} 
ecological resources that underpins such transformations, in the context of historical political economy, is necessary to understanding historical urban processes often assumed to be apolitical and unecological.

Reformers' ideas about how working-class people related to nature, the benefits they might derive from it and thus the forms nature might take in working-class residential neighbourhoods, changed over the nineteenth century. In the 1840s, sanitary concerns dominated; only later did reformers begin to emphasize the immaterial benefits of natural spaces to the urban poor. Acknowledging the intellectual and moral capacity of poor, uneducated people to appreciate natural beauty drove reformers to work to keep green spaces out of the urban property market, preserving them for all Londoners. Yet rented housing was subject to the disciplining hand of the price mechanism, which over time drove working-class people to seek lower rents further away from these pleasant environments, whose benefits were captured by wealthier Londoners.

As urban political ecologist Erik Swyngedouw suggests, processes of socioenvironmental change are never socially or ecologically neutral, since such change 'results in conditions under which particular trajectories of socio-environmental change undermine the stability or coherence of some social groups or environments, while the sustainability of others elsewhere might be enhanced'. ${ }^{79}$ As we have shown here, it was the housing reformers and urban capitalists, rather than the working classes, who held privilege within the institutional, material and discursive relations that combined to define and create conditions for the socio-ecological improvement of working-class lives. On their part, the reformers' complex and contradictory conceptualization of nature as it pertained to urbanization and the workings of a capitalist economic system enabled but also limited the extent of the socio-ecological improvements they sought. Relatedly, reformers sought to bring about those improvements in ways that preserved their own, or the capitalists', socio-power position within the industrial urban political economy, at the expense of poorer populations.

Reformers devoted their time, energy and creativity to improving working-class housing, but also to reinforcing the free-market ideology that the existence of slums brought into question. Because this ideology was a human creation, and not a 'natural' law as its proponents portrayed it, it took effort and ingenuity to create schemes for financing better working-class housing that did not visibly contravene the principles of political economy. Indeed, because these principles were so widely held by the property-owning classes in the mid-nineteenth century, it was only by convincing supporters that their work did not deviate from this dominant ideology that reformers could access the necessary capital for their projects. Adherence to free-market principles was thus a necessity for reformers, but their work in turn bolstered belief in these principles because it purported to show that the existence of slums was an aberration from, not a result of, unregulated urban housing markets. Godwin, Hill and Barnett each focused their efforts on small projects intended to serve as models for others. However, it was not until the London County Council began to build homes that the housing needs of the poor began to be met on an

\footnotetext{
${ }^{79}$ E. Swyngedouw, 'The political economy and political ecology of the hydro-social cycle', Journal of Contemporary Water Research \& Education, 142 (2009), 56-60.
} 
adequate scale. The small projects never fulfilled their stated function of inspiring enough private investors to solve the housing shortage. They did, however, serve to shield laissez-faire liberalism from critique, thus upholding the social and economic status quo, leaving power and wealth in the hands of those who already possessed them.

For Victorian housing reformers, capturing the benefits of nature was central to capitalist urbanization. In this context, therefore, urban slums came to be seen as unnatural, since they defied the presumed free-market logic of equitable and efficient resource allocation, but also lacked the environmental resources necessary for a healthy human life. Housing reformers attempted to redeem these urban spaces by reintroducing nature into them. The specific natural resources varied from simple air, water and sunlight, to green spaces, cut flowers and gardens; but traditional celebrations, medieval-inspired architecture and even 'sound finance' were also viewed as natural and thus endowed with the power to transform slums into healthy residential districts. The persistent failure of working-class residential districts to respond to market forces by increasing the supply of safe and sanitary housing, as those who believed in supply and demand as a law of nature assumed they would, contributed to the notion that these urban spaces were artificial.

Ultimately, by conflating biological and social processes and assigning the status of universal laws to socially constructed concepts, reformers often undermined their own efforts to improve the well-being of all urban dwellers and to distribute social and environmental benefits more justly across urban spaces. Through the housing improvement schemes discussed here, a number of working-class families those who could demonstrate the 'respectable' behaviours elicited by reformers benefited from improved living conditions or from knowing influential patrons who could match them to better job opportunities. Investors in the housing projects also benefited by making their modest but guaranteed profit. When publicly accessible green spaces were preserved, subsequent generations of Londoners have also benefited. However, due to the working of the real estate market, properties nearer to these green spaces have risen in price so that it is wealthier residents who have access to spaces like Hampstead Heath. ${ }^{80}$ Meanwhile, to make privately owned social housing projects appear financially sound and profitable, local governments subsidized their efforts in various ways, including allotting land to them that could have been sold or rented much more profitably, so that taxpayers paid while landlords benefited. And while some working-class families were able to improve their conditions, others, especially those already living more precariously due to challenges such as casual or seasonal employment or a family member's problematic behaviours, found themselves excluded altogether from their homes.

\footnotetext{
${ }^{80}$ Wolch et al. have described similar processes of 'eco-gentrification' in China: 'Urban green space, public health, and environmental justice: the challenge of making cities "just green enough", Landscape and Urban Planning, 125 (2014), 234-44.
}

Cite this article: Grant AC, Njeru J (2022). Sunlight and free markets: an urban political ecological perspective on social housing in Victorian London (1850-1914). Urban History 1-21. https://doi.org/ $10.1017 /$ S0963926821000857 